\title{
Chapter 19 \\ Placing the University: Thinking in and Beyond Globalization
}

\author{
Allan Cochrane
}

For many of those who work in them, universities simply are. We (for I am one of those who does) take them for granted as our workplaces, often to the extent that, as Calhoun (2006) sardonically comments, "Professors tend to think universities exist naturally, or as a gift of history, in order to employ them" (p. 34). But, of course, it is increasingly difficult to maintain such a position. There was always a tension between a vision of the academy (as a more or less global thought community) and the university (as an institution in place). And even the most insulated of academics must be aware of the changes that have been shaping and reshaping higher education in the last few decades with the shift from elite to mass higher education, the rise of a more market-based approach to study, the increase of competition globally and locally, the growth of the expectation that universities will contribute to economic and social development, and so on (see, e.g., Goddard \& Vallance, 2013, for a thoughtful engagement with the wider debates about the relationship between universities and urban development).

\section{Changing Spatial Imaginaries}

These changes have also been associated with changes in the ways in which the geographies of universities have been imagined. The contested and overlapping conceptualizations of the geographies of higher education provide a powerful way into thinking about the contemporary university. These can be briefly summarized. The first (traditional) version imagines academic life in terms that resist any sense of spatial fixity or embeddedness. It celebrates knowledge for its own sake as expressed

\footnotetext{
A. Cochrane $(\bowtie)$

Faculty of Arts \& Social Sciences, The Open University, Milton Keynes, UK

e-mail: allan.cochrane@open.ac.uk 
through networks of academia that stretch beyond, into national and global networks. From this perspective, place does not matter-where a university is located is barely relevant (except sometimes as an irritant) to the life of those connected into those networks. Elite universities may be located in place, but that does not mean that they understand themselves as being of the place in which they find themselves. The second (globalized) version seems equally reluctant to accept the restrictions of territorial identity, but in this case the emphasis is on the global markets expressed in student mobility and the transferability of qualifications, the possibilities of overseas and campuses, as well as the promise of virtual higher education (through Massive Open Online Courses, or MOOCs). It is also accompanied by an obsession among elite or "wannabe" elite institutions with their position in global rankings of one sort and another (as expressed, for example, in the extensive publications associated with the Observatory on Borderless Higher Education, n.d.). The third (regionalized) version also starts from within the vision of a globalized knowledge economy but in this case one in which universities themselves are placed as development nodes and transmission belts and as active partners in communities (Harding, Scott, Laske, \& Burtscher, 2007; Organization for Economic Cooperation and Development [OECD], 2007). It connects to a longer tradition with an emphasis on the potential of civic universities and (in the U.S. context) service learning (see, Goddard, 2009).

Of course this summary is not an exhaustive one. Although there has undoubtedly been a shift toward global narratives, identified as a "revolution" by Altbach, Reisberg, and Rumbley (2009), there is a parallel political world dominated by national policy initiatives, which are themselves shaped by the attempts of national governments to make their higher education systems deliver on a range of priorities, some of which are often expressed in a language of global competitiveness (as reflected, for instance, in the claims made by Universities UK, 2015). So, in England, for example, it is currently impossible for any university (however hard it tries and whatever its global ambitions) to ignore the implications of a hybrid national funding regime apparently sustained through the payment of student fees, but in practice underpinned by state-backed loans (McGettigan, 2013).

It would also be a mistake to see these different versions as somehow alternatives, in the sense that any one of them captures the reality of contemporary higher education. On the contrary these are active geographies, mobilized in different ways at different times, often by the same players. And what matters is how these imaginaries are mobilized to justify particular institutional strategies and to incorporate a range of different higher education actors - not just senior managers (or leaders as they increasingly call themselves), but also academics, students, and even a wider range of those who are from time to time identified as stakeholders, including local and regional government agencies, as well as national governments and funding agencies, both private and public.

In this context, it is helpful to reflect on some of the myths that swirl around universities. The old myth of the ivory tower, dedicated to research and study is of course, as Calhoun (2006) suggests, highly attractive to many academic staff. Perhaps no one has ever actually worked in such an institution and none probably ever existed, but it is comforting to know that it might have. This myth is frequently 
presented from the outside as one that positions academics as an elite disconnected from the problems and possibilities of the "real" world, with the new myths seeming to offer a very different take, even if the elite status of the academy remains central to them. The university is constructed as a special place of expertise and knowledge production, but now the task is to find ways in which our knowledge can be transferred from us to "them" in a language of impact, knowledge transfer, and engagement. At its most inspiring this is translated into a language of missionswith the missionary complex of universities hard to miss in their official statements seeking to define their roles - and contribution to the public good, as well as to economic transformation. The mission of the University of Cambridge "is to contribute to society through the pursuit of education, learning and research at the highest international levels of excellence" (University of Cambridge, n.d.); that of the Open University is "to be open to people, places, methods and ideas" and to "promote educational opportunity and social justice by providing high-quality university education to all who wish to realise their ambitions and fulfil their potential" (The Open University, n.d.).

Significant claims are increasingly being made about the importance of universities for their regional economies and societies. It is believed they are central to building competitiveness (e.g., through their role in the knowledge society and knowledge exchange), as well as contributing to the transformation of local populations through upskilling and reskilling (see chapters of Etzkowitz; Glückler, Panitz \& Wuttke; Goddard in this volume) They are understood to be powerful agents of cultural change, as well as potential sources of initiatives to challenge social disadvantage (as no more than an indicative and far from comprehensive list see, for example, Addie, Keil, \& Olds, 2015; Benneworth, 2012; Benneworth \& Hospers, 2007; Goddard \& Vallance, 2013; Harding et al., 2007; Kitigawa, 2004; OECD, 2007; Pinheiro, Benneworth, \& Jones, 2012; Pinheiro, Langa, \& Pausits, 2015; Rohe, 2011; Sir Witty, 2013; Stachowiak, Pinheiro, Sedini, \& Vaattovaara, 2013; Yusuf \& Nabeshima, 2007).

\section{Universities as Institutions}

All of this in its different ways starts from the assumption that somehow universities have a special role, whether in their ivory tower or in enabling processes of change. Much of the writing emanates from universities, of course, and where it does not, it is clearly targeted at celebrating their role (see, e.g., Etzkowitz, 2008; Etzkowitz \& Leydesdorff, 1997).

This chapter has a rather different starting point. Instead of assuming a special status for universities (and their staff), it seeks to understand them through their institutional and discursive practices - as far as possible looking at them from the outside in the same way as academic researchers do when exploring how other organizations operate. That is to say, it is framed by the nagging question, "what if we are not so special after all?" The aim is to think differently, moving beyond 
academic and institutional self-regard to reflect on the ways in which universities operate as more or less successful businesses, positioning themselves within and attempting to influence the changing geographies of knowledge production and knowledge exchange.

The reflections that follow are informed by and build on work initially undertaken with colleagues at the Open University and the University of East Anglia from 2008 to 2010 (Michael Amoah, Alice Bennion, John Brennan, Yann Lebeau, and Ruth Williams) as part of an Economic and Social Research Council funded project on Higher Education and Social and Regional Transformation (ES/E017894/1). This project has also led to the publication of a book (Brennan et al., 2018). However, the conclusions that I draw from this work are very much my own, and I would not want any of my colleagues to face criticism for anything that is said here-they may well disagree! The research was conducted on four universities located in different regional contexts across the United Kingdom, each with its own particular institutional mission. It involved the review of a wide range of documents (strategic plans, mission statements, and more) as well as extensive interviews with university staff, local business and community stakeholders (including other universities in the region), as well as hybrid or partnership organizations working with or around universities, ranging from agencies seeking to foster widening participation by people from socially disadvantaged groups to those associated with the promotion of science or technology parks.

It is impossible to capture the full variety of universities in ways that fully reflect the significance of differences between them. But the four cases explored in the research make it possible to consider some of the ways in which the universities, each in its own way, sought to engage with and actively define the spaces of higher education. A range of options was being mobilized and managed by universities in the face of the challenges generated by the changing political economy of higher education. The experiences the research team identified are far away from some of the more visionary expressions of the role of universities. The extent to which these institutions were operating in worlds not of their own making and needing to negotiate with others was apparent. It was also clear that they sought to draw on a range of resources at their disposal to bring in funding as well as other resources from elsewhere-student fees (domestic and international), funding bodies, and other private and public sources. Institutional survival and expansion were significant drivers, even if they were often expressed in apparently well-meaning statements of intent about community, economic contribution, and cultural transformation. Of course, as with all institutions, it is important to acknowledge that their identity is more complex and less unitary than this implies-the acts of individual academics or their collective actions may sometimes fit uneasily with stated and implicit corporate priorities. But it is nevertheless possible to identify institutional framings within which even the most troublesome of individual players find themselves positioned (for some of the tensions see, Rolfe, 2012). 


\section{Universities in Their Regions}

The universities and regions on which the project focused may not deliver an exhaustive set of potential cases, but they do provide some key illustrative evidence. It was apparent that the specifics of each case were significant, even as it was possible to draw out wider conclusions. The experience of the four institutions can be summarized along the following lines:

Case 1: Wannabe global city regionalism In this case, the university had a clear strategy of positioning itself as a global institution (and was highly ranked in international tables of university reputation), while at the same time the city was attempting to define itself as a global city, or at the heart of an emergent global city region. In both instances the extent to which each actor had the capacity to take on these global roles may have been questionable, but in each it translated into a powerful positioning within the national context. The university attracted students from across England, as well as from overseas, although a significant proportion were drawn from the wider region in which it was located. The university was centrally positioned as a change agent and was supported in its development ambitions by local and regional agencies. This was reflected in a continuing process of property development, making up an urban campus in the heart of the city and dramatically transforming one of the main transport arteries as it does so. The university's strategic plan described the success of the city region as being vital to the university's own chances of realizing its ambitions and also declared the institution's commitment to working with city authorities to enhance the standing of the city as a dynamic node in the global knowledge economy.

Case 2: Local of necessity The university was located within a declining industrial area with a poor external image, with a student body largely drawn from that area. It was understood by stakeholders to be the local university within its urban subregion, but there was a division of labor with another (more elite-oriented) university that had a branch campus in the same region. It presented itself as a business university, oriented toward the needs of local businesses, although not providing the elite labor force required to support the specialist work undertaken within some of the local industries. The main campus of the university was located in one of the subregion's urban centers, and mayor, council, and university actively engaged with each other to challenge the region's negative external image - making it attractive to potential students as well as investors are seen as complementary processes. The investment in and development of the central campus had helped to shape a modest university quarter and had begun to open up consumption based services around the university. The university had drawn on local and regional support to develop new campuses and new areas of curriculum and research, identifying and building on particular institutional strengths, such as digital media, in the global market place. Such initiatives both repositioned the university as more than local and were intended to shift perceptions of the city from a home of old industry to a center for emerging industries. 
Case 3: Inventing a (sub)region Here the uncertainty of the university's position was particularly striking. It operated within a complex (mega)city region, with many institutions and blurred boundaries. Its focus was on recruiting students with relatively low educational qualifications, often from black and minority ethnic populations. This was a quintessentially urban institution whose identity was defined by the broadly defined subregion in which its campuses had historically been located, although it had sought to concentrate its activities on a more limited number of sites. The urban area in which the university was based had been the subject of major regeneration initiatives over the last 25 years, as well as being the site of at least one mega project and one significant private-sector-led development project. This had also created opportunities for the university as partner. It had learned to play the regeneration game, often responding to the possibilities created by the operation of development agencies, moving into new spaces and taking advantage of development opportunities as it had created its new campuses and sought to collaborate with other universities to create shared spaces. It had attracted some criticism from those left behind when old campuses have closed, but had sought to maintain its imagined place-based identity. The process of identity formation was fragile, but often confident, as academics also engaged in the process of place definition in their writing and promotion of workshops rooted in the local experience.

Case 4: Geographically embedded The fourth case was of a university that operated within a narrowly defined local geography, in a city that had faced major problems of economic restructuring over the past few decades. Even more than the other institutions this university saw itself as responding to national (in this case Scottish) policy, but its students were predominantly local. Like Case 2, it had sought more effectively to concentrate its activity, in this case to a more central campus within the city. There was a clear division of labor between this university and the city's other (more elite and much larger) university, which attracted students from a wider catchment area within Scotland. In this context the university identified a carefully focused set of ambitions that emphasized work in the areas of environmental sciences, policing, forensics, and criminal justice, as well as in inclusive technologies for sustainability, well-being, and security. There was an implicit partnership between the universities in terms of the way in which they came together to find ways of reimagining the city, enabling it to escape from past associations with decline by creating a cultural quarter, incorporating the campus, and seeking to transform place. In this, the university was part of a wider public-private partnership aiming to reposition the city as a place for the future, although some of the academics interviewed raised concerns about the extent to which this approach effectively excluded those more disadvantaged people outside the transformed center who had previously been served by the institution.

In all four cases, it was possible to identify ways in which the places of the university were being actively reimagined. There was a complex dance in which institutional self-image and the presentation of place were brought together (Cochrane \& Williams, 2013). At first glance there is a surprising alignment of 
regional and local priorities with university priorities despite the different drivers to which each seemed to be responding. So in one case there was an alignment between the local ambitions to be a world city and university ambitions to be a global university; in another there was a coming together around the vision of developing a digital city and the ambition to be a center of digital media; in a third the two were focused on the prospects of large scale urban regeneration; while in the fourth, there was a promise of synergy around the university and city in fostering a creative city and creating a cultural center.

\section{The Everyday Practices of Universities in Place}

But it is also necessary to reflect on some of the mundane stories of transformation associated with universities and their development-without having any particular strategic focus on locality or region, what universities do may nevertheless have a dramatic impact on place. And the day-to-day activity of most universities will of necessity involve them in formal and informal negotiation as major employers, major landowners, and major developers of property, often in high-value, central areas and sometimes on the edge of cities. It is clear (and presumably not controversial to note) that the business strategies of universities are driven by their own priorities - student recruitment, income generation, and survival, even if, as McGettigan (2013) notes, the marketized rules of the game have changed the ways in which those priorities are pursued. Of course, this is sometimes veiled by a language of social mission or commitment to disinterested knowledge production, and the ways in which many staff espouse such ambitions is sincere enough. But wider institutional logics are stubbornly apparent, however much some members of academic and other staff seek to position themselves outside or beyond them.

One of these relates to the extent to which universities are adept at playing the grant-getting game, playing by the rules in ways that benefit them as institutions and ways that position them as regional players. So, for example, without necessarily changing the main direction of activity, all of the institutions visited responded directly to initiatives launched by university funding councils-for example, in the New Labour era forming partnerships in the context of Aimhigher (targeted at widening participation) or around the Beacons initiative, which was specifically targeted at developing forms of public engagement. Once the funding was withdrawn, most of the specific activities ceased unless they could be incorporated (costlessly) into the mainstream activities of the universities. All of them also participated in local and regional partnerships, in formal ways (for example through the representation of senior staff on partnership boards of various sorts) but becoming more actively engaged when such bodies were identified as potential sources of funds - for example in enabling the development of new campuses in the context of regeneration or in sponsoring institutional mergers that strengthened their position nationally as well as locally. 
The institutional thrill of property development was frequently apparent. All of the universities were engaged with other local agencies in a series of property-related initiatives. The development of new campuses and the expansion and rationalization of existing ones was a feature in all four cases. In one the scale was such that it was the focus of a development partnership involving the city council as well as other partner agencies (such as the local hospital trust) and offered the prospect of transforming a significant area of the city. The university's institutional priorities were incorporated into the city's wider growth ambitions, as its civic leaders sought to move from an older industrial base to a service-based and possibly even knowledge-based or creative economy. In the other instances, although the scale was less ambitious, similar trends were apparent—as in one case the campus was consolidated; in a second a new campus was developed in the context of wider urban regeneration strategies; while in a third stress was placed on creating a cultural area around an urban campus, in sometimes uneasy collaboration with another local university.

But perhaps the most significant impact some universities have on the areas in which they are located has little to do with any straightforward regional or placebased institutional strategy. Instead what may matter more are the practices of higher education as a business, both in the ways they operate and in the consequences of their operation. Universities have a significant impact as businesses in their own right, both through their property strategies and as big employers of technical and professional staff (including but not only knowledge professionals). In many cities universities are the largest single employer, rivaled only by the National Health Service and (until recently at least) local government. In the context of significant regional inequality across England, they are unusual in offering comparable rates of pay as part of a national (and even global) higher education system. In this context, although less evenly, they may also act as nodes for the transmission of globalized competitive agendas emphasizing the significance of the knowledge economy and fostering or providing environments within which the language of digitization and creativity is increasingly taken for granted.

The unintended consequences of university activity for places are as important as the planned or intended ones. That is the case with property development initiatives that transform particular areas, introducing new uses and moving older ones (and sometimes older populations) away in the context of strategies whose core purpose is to underpin the university's own further development, even as it is sometimes framed in partnership terms through the rhetoric of wider ambitions to urban regeneration. Meanwhile, the significance of studentification has been increasingly widely acknowledged (see, e.g., Smith, 2008, Smith \& Hubbard, 2014). As full-time student numbers in England have increased inexorably since the early 1990s, new consumption patterns have developed in many of England's older cities, and housing tenure patterns have changed, too, as some areas have effectively become dominated by student rental housing, whether houses in multiple occupation or in the form of purpose-built student accommodation.

This was a particular issue at one of the researched institutions, with interviews eliciting ambiguous responses from residents and local political actors: A residents' 
association highlighted the changing demographics of their area, noting that houses were often empty for long periods in vacation time and complaining that some traditional shops had gone to be replaced by others more focused on the student market; in the central area of the city, the local authority was more positive, highlighting the extent to which a more exciting ( 24 hour) economy was being generated, which made the city more attractive to visitors and potential campus investors. Instead of a reputation for industrial decline it was possible to call on a series of images from a more vibrant youth culture (for a more critical view, see Chatterton, 1999). Matters were less clear-cut in other cases where the student body was more local and often part-time, living at home. Even here, however, there was some evidence in two of the cases that new consumption activities were being enabled around the university.

During the period of research, one of the most actively pursued policies linking higher education to a wider social mission, which also had an implicit and sometimes explicit regional focus related to widening participation, and in their different ways all of the institutions had their own widening participation strategies. These strategies varied significantly between institutions. For the university most clearly identifiable as an "elite" institution (in the wannabe global region), widening participation was seen in terms of a responsibility to raise aspirations in local schools, in a sense inspiring pupils by fostering an engagement with education, showing what was possible. There was no particular expectation that the students inspired in this way would attend the university, since the emphasis was on recruiting across the United Kingdom and was focused on applicants with high entry qualifications. A similar approach was taken by another elite university that had a campus in the same subregion as the institution identified as local of necessity. It too saw its job as being to bring ideas from outside into the local context, without any expectation that local young people would necessarily become its students, although they might be inspired to pursue routes into higher education.

The other three universities were far more oriented toward the recruitment of students previously at risk of exclusion from higher education, with partnerships with local schools being oriented toward that recruitment. In a sense recruitment of students with lower educational qualifications was a central aspect of their business plans as much as it was a social mission. Within the project's four subregions, widening participation activities tended to provide social mobility opportunities for the few without necessarily altering patterns of inequality that affect the many, as one of our respondents commented. And in the subregions with several higher education providers, the implicit stratification of institutions mapped onto and reinforced wider patterns of inequality. One of our (private sector) respondents commented that by playing the "local" card in developing its curriculum, the university identified as local of necessity was effectively positioning its students in ways that left them disadvantaged, even as others commented that those with qualifications tended to use them to find employment outside the region. 


\section{Conclusions: The Many Spatialities of Higher Education}

From different perspectives, although sometimes in the same strategic plans, universities can be understood to be everywhere, nowhere, and somewhere. The language of globalized higher education tends to focus on their ubiquity - they can be accessed virtually through MOOCs or otherwise; or by more traditional face-toface means through an increasingly wide range of distributed campuses and partnerships associated with home institutions mainly based in the United Kingdom, the United States, or Australia; and, of course, the transnational mobility of students means that institutions stretch their connections far beyond any territorial or national borders. Alongside this form of globalized language, an older tradition survives that emphasizes the existence of a global academy, in which it is ideas and key thinkers or thinking that straddle the globe. In principle, institutional location is secondary to the networks of globalized academics meeting in conferences and workshops, writing for international journals, and sometimes even enjoying global reputations of their own.

And yet, universities are generally (even if not always) more or less fixed in place. This means that they always have a relationship with their regions, even if that is not what frames university strategies. Their day-to-day activities often have significant local and localized impacts. Their images and brands can help to define the places within which they are located, just as those locations can help to define the universities and the student markets on which they are able to draw. In other words, universities shape and are shaped by the places within which they find themselves. So, even as they are always necessarily connected to elsewhere, stretching out for students, funding, ideas, and academic networks, they are also necessarily located in place by the practices of everyday institutional life, often including significant sunk investment in infrastructure, in addition to any formal civic commitment they may espouse. In that sense, not only are they both global and local, but their local presence is formed through their global ambitions or global positioning, while the versions of globalization they help to construct are also formed through practices of local emplacement.

\section{References}

Addie, J.-P. D., Keil, R., \& Olds, K. (2015). Beyond town and gown: Universities, territoriality and the mobilization of new urban structures in Canada. Territory, Politics, Governance, 3, 27-50. doi:https://doi.org/10.1080/21622671.2014.924875

Altbach, P. G., Reisberg, L., \& Rumbley, L. E. (2009). Trends in global higher education: Tracking an academic revolution. Paris: UNESCO.

Benneworth, P. (Ed.) (2012). University engagement with socially excluded communities. Dordrecht: Springer. 
Benneworth, P., \& Hospers, G.-J. (2007). Urban competitiveness in the knowledge economy: Universities as new planning animateurs. Progress in Planning, 67, 105-197. doi:https://doi. org/10.1016/j.progress.2007.02.003

Brennan, J., Cochrane, A., Lebeau, Y., \& Williams, R. (2018). The university in its place: Social and cultural perspectives on the regional role of universities. Heidelberg: Springer.

Calhoun, C. (2006). The university and the public good. Thesis Eleven, 84(1), 7-43. doi:https://doi. org/10.1177/0725513606060516

Chatterton, P. (1999). University students and city centres - the formation of exclusive geographies: The case of Bristol UK. Geoforum, 30, 117-133. doi:https://doi.org/10.1016/S00167185(98)00028-1

Cochrane, A., \& Williams, R. (2013). Putting higher education in its place: The socio-political geographies of English universities. Policy and Politics, 41, 43-58. doi:https://doi.org/10.1332/ 030557312 X645775

Etzkowitz, H. (2008). The Triple Helix: University-industry-government innovation in action. Abingdon: Routledge.

Etzkowitz, H., \& Leydesdorff, L. (Eds.). (1997). Universities in the global knowledge economy: A triple helix of university-industry-government relations. London: Continuum.

Goddard, J. (2009). Re-inventing the civic university. London: National Endowment for Science, Technology and the Arts.

Goddard, J., \& Vallance, P. (2013). The university and the city. Abingdon: Routledge.

Harding, A., Scott, A., Laske, S., \& Burtscher, C. (Eds.). (2007). Bright satanic mills: Universities, regional development and the knowledge economy. Aldershot: Ashgate.

Kitigawa, F. (2004). Universities and regional advantage: Higher education and innovation policies in English regions. European Planning Studies, 12, 835-852. doi:https://doi.org/10.1080/ 0965431042000251882

McGettigan, A. (2013). The great university gamble: Money, markets and the future of higher education. London: Pluto.

OECD (Organization for Economic Cooperation and Development). (2007). Higher education and regions: Globally competitive, locally engaged. Paris: OECD.

Observatory on Borderless Higher Education. (n.d.). Retrieved from http://www.obhe.ac.uk/what_ we_do/news_articles_reports/news_articles_reports

Pinheiro, R., Benneworth, P., \& Jones, G. A. (Eds.). (2012). Universities and regional development: A critical assessment of tensions and contradictions. Abingdon: Routledge.

Pinheiro, R., Langa, P. V., \& Pausits, A. (2015). One and two equals three? The third mission of higher education institutions. European Journal of Higher Education, 5, 233-249. doi:https:// doi.org/10.1080/21568235.2015.1044552

Rohe, W. M. (2011). The research triangle: From tobacco road to global prominence. Philadelphia: University of Pennsylvania Press.

Rolfe, G. (2012). The university in dissent: Scholarship in the corporate university. Abingdon: Routledge.

Sir Witty, A. (2013). Encouraging a British innovation revolution: Sir Andrew Witty's review of universities and growth. London: Department of Business, Innovation and Skills.

Smith, D. P. (2008). The politics of studentification and '(un)balanced' urban populations: Lessons for gentrification and sustainable communities? Urban Studies, 45, 2541-2564. doi:https://doi. org/10.1177/0042098008097108

Smith, D. P., \& Hubbard, P. (2014). The segregation of educated youth and dynamic geographies of studentification. Area, 46, 92-100. doi:https://doi.org/10.1111/area.12054

Stachowiak, K., Pinheiro, R., Sedini, S., \& Vaattovaara, M. (2013). Policies aimed at strengthening ties between universities and cities. In S. Musterd \& Z. Kovács (Eds.), Place-making and policies for competitive cities (pp. 263-291). Chichester: Wiley-Blackwell. doi:https://doi. org/10.1002/9781118554579.ch16 
The Open University. (n.d.). Mission. Retrieved from http://www.open.ac.uk/about/main/mission University of Cambridge. (n.d.). The university's mission and core values. Retrieved from https:// www.cam.ac.uk/about-the-university/how-theuniversity-and-colleges-work/the-universitysmission-and-core-values

Universities UK. (2015). The funding environment for universities 2015: The economic role of UK universities. London: Universities UK. Retrieved from http://www.universitiesuk.ac.uk/policyand-analysis/reports/Documents/2015/the-economic-role-of-uk-universities.pdf

Yusuf, S., \& Nabeshima, K. (Eds.). (2007). How universities promote economic growth. Washington: World Bank.

Open Access This chapter is licensed under the terms of the Creative Commons Attribution 4.0 International License (http://creativecommons.org/licenses/by/4.0/), which permits use, sharing, adaptation, distribution and reproduction in any medium or format, as long as you give appropriate credit to the original author(s) and the source, provide a link to the Creative Commons license and indicate if changes were made.

The images or other third party material in this chapter are included in the chapter's Creative Commons license, unless indicated otherwise in a credit line to the material. If material is not included in the chapter's Creative Commons license and your intended use is not permitted by statutory regulation or exceeds the permitted use, you will need to obtain permission directly from the copyright holder. 